\title{
PHYSIOLOGICAL DISTURBANCES AT CRITICALLY HIGH TEMPERATURES: A COMPARISON BETWEEN STENOTHERMAL ANTARCTIC AND EURYTHERMAL TEMPERATE EELPOUTS (ZOARCIDAE)
}

\author{
P. L. M. VAN DIJK ${ }^{1, *, \$}$, C. TESCH ${ }^{1}$, I. HARDEWIG ${ }^{1, *}$ AND H. O. PÖRTNER ${ }^{1}$ \\ ${ }^{1}$ Alfred Wegener Institute for Polar and Marine Research, Biology I/Ecophysiology, Columbusstrasse, 27568 \\ Bremerhaven, Germany \\ *Present address: Institute of Freshwater Ecology and Inland Fisheries, POB 850119, 12561 Berlin, Germany \\ †e-mail: vandijk@igb-berlin.de
}

Accepted 30 September; published on WWW 29 November 1999

\begin{abstract}
Summary
The effect of gradually increased water temperature on the metabolism of temperate eelpout from the North Sea (Zoarces viviparus) and Antarctic eelpout (Pachycara brachycephalum) was investigated. Standard metabolic rate (SMR) was similar in cold-adapted $P$. brachycephalum and cold-acclimated $Z$. viviparus in the low temperature range. This indicates that Antarctic eelpout show no metabolic cold adaptation (as originally defined by Wohlschlag); however, they do show a compensatory increase of oxygen consumption compared to warm-acclimated eelpout. SMR increased more strongly with rising temperature in $P$. brachycephalum than in $Z$. viviparus, which is reflected in a higher Arrhenius activation energy for oxygen consumption $\left(99 \pm 5 \mathrm{~kJ} \mathrm{~mol}^{-1}\right.$, versus $55 \pm 3 \mathrm{~kJ} \mathrm{~mol}^{-1}$ for cold-acclimated $Z$. viviparus; means \pm S.D.).

The intracellular $\mathrm{pH}$ in the white musculature of $Z$. viviparus follows alphastat regulation over the whole

The upper critical temperature limit ( $T \mathrm{c}_{\text {III }}$; characterised by a transition to anaerobic metabolism) was found to be between $21^{\circ} \mathrm{C}$ and $24^{\circ} \mathrm{C}$ for $Z$. viviparus and around $9{ }^{\circ} \mathrm{C}$ for $P$. brachycephalum. In both species a rise of succinate concentration in the liver tissue turned out to be the most

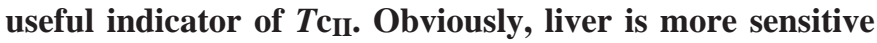
to heat stress than is white muscle. Accordingly, the energy status of white muscle is not diminished at $T_{\mathrm{c}}$. Heatinduced hyperglycaemia was observed in Antarctic eelpout (at $9^{\circ} \mathrm{C}$ and $10^{\circ} \mathrm{C}$ ), but not in common eelpout. Based on our results and on literature data, impaired respiration in combination with circulatory failure is suggested as the final cause of heat death. Our data suggest that the southern distribution limit of Zoarces viviparus is correlated with the limit of thermal tolerance. Therefore, it can be anticipated that global warming would cause a shift in the distribution of this species.
\end{abstract} investigated temperature range and dropped at a rate of $-0.016 \mathrm{pH}$ units per ${ }^{\circ} \mathrm{C}$ between $3^{\circ} \mathrm{C}$ and $24^{\circ} \mathrm{C}$. In Antarctic eelpout white muscle $\mathrm{pH}$ declined at a rate of $-0.015 \mathrm{pH}$ units per ${ }^{\circ} \mathrm{C}$ between $0^{\circ} \mathrm{C}$ and $3{ }^{\circ} \mathrm{C}$, but deviated from alphastat at higher temperatures, indicating that thermal stress leads to acid-base disturbances in this species.
Key words: global warming, heat exposure, heat death, temperatureinduced anaerobiosis, succinate, oxygen consumption, Arrhenius activation energy, free energy change of ATP hydrolysis, acid-base regulation, alphastat regulation, intracellular $\mathrm{pH}$, fish, Zoarces viviparus, Pachycara brachycephalum.

\section{Introduction}

The survival of ectothermic organisms, and thus the distribution of species, is closely related to the ambient temperature regime. Ectothermic organisms tolerate fluctuations of the habitat temperature only within certain limits. Consequently, drastic as well as gradual climate changes during the earth's history have always led to new distribution patterns of species. Global warming is not only predicted to bring about a rise in mean annual temperatures but also to cause an increase in the seasonal differences between winter minimum and summer maximum temperatures in temperate regions (Mohnen and Wang, 1992). In this respect it is interesting to note that, over the last decades, global warming has actually already caused subtle changes in the distribution of species (Southward et al., 1995).

There is little information about which physiological processes are impaired at critically high temperatures and which may contribute to setting the lethal temperature limits of an organism. In invertebrates, the low $\left(T \mathrm{c}_{\mathrm{I}}\right)$ and high $\left(T \mathrm{c}_{\mathrm{II}}\right)$ critical temperature limits are characterised by the onset of anaerobic metabolism (Pörtner et al., 1998). For the sipunculid worm, Sipunculus nudus, $T_{\mathrm{c}}$ was determined to be between $0^{\circ} \mathrm{C}$ and $4{ }^{\circ} \mathrm{C}$. Below $4{ }^{\circ} \mathrm{C}$ ventilation decreased and caused the 
animal to become hypoxic, which was indicated by the accumulation of anaerobic endproducts such as succinate, propionate and acetate in the body wall musculature and the coelomic fluid (Zielinski and Pörtner, 1996). In this species temperature-induced anaerobiosis is an early indication of the lethal temperature threshold. Similar results were found for the lugworm, Arenicola marina (Sommer et al., 1997). A comparison of two populations of this species from different latitudes showed that evolutionary adaptation to colder habitats results in a shift of both $T \mathrm{c}_{\mathrm{I}}$ and $T \mathrm{c}_{\mathrm{II}}$ to lower temperatures. A downward shift of the critical temperatures during evolutionary cold adaptation is also observed in Antarctic species.

Since the thermal conditions in the Southern Ocean have been quite constant for the last several million years and seasonal variations are minimal, the inhabiting fauna has become highly adapted to cold, but has also become extremely stenothermal. Somero and DeVries (1967) measured an upper incipient lethal temperature for some Antarctic Notothenioid fish species of only $6{ }^{\circ} \mathrm{C}$. In contrast, temperate, eurythermal species are subjected to a much broader temperature range, with the apparent advantage that temperature-sensitive processes such as growth and reproduction can occur during more favourable seasons. Against this background it is interesting to evaluate whether the characteristics of thermal stress are similar in steno- and in eurythermal species. This question can be most adequately addressed in animal groups where confamilial species are found in polar as well as in temperate waters. The fish family Zoarcidae, being cosmopolites, are therefore well suited for such comparative studies. In the present study, we compared the eurythermal temperate eelpout from the North Sea, Zoarces viviparus, with the stenothermal Antarctic eelpout, Pachycara brachycephalum.

We investigated whether stenothermal Antarctic and eurythermal temperate eelpout show adaptive differences of the metabolic rate and whether this may relate to different levels of thermal tolerance. It is still a matter of discussion whether adaptation to polar conditions has led to an increase in the standard metabolic rate in Antarctic fish, a phenomenon termed metabolic cold adaptation (MCA; Wohlschlag, 1964). The MCA controversy has been reviewed previously by Clarke (1991). Furthermore, we wanted to find out whether similar processes are impaired at temperatures above $T \mathrm{c}_{\text {III }}$. Is the onset of anaerobic metabolism at water temperatures above a critical threshold, so far only reported for invertebrates, also a characteristic phenomenon in fish?

\section{Materials and Methods}

Animals

Antarctic eelpout, Pachycara brachycephalum, were caught near King George Island $\left(61^{\circ} 43.3^{\prime} \mathrm{S}, 59^{\circ} 12.5^{\prime} \mathrm{W}\right)$ at a depth of $500 \mathrm{~m}$. Baited traps, which had been kept at the bottom for $36 \mathrm{~h}$, were slowly raised $\left(\leqslant 0.5 \mathrm{~m} \mathrm{~s}^{-1}\right)$ to allow the animals to adjust gradually to the falling pressure. The fish (mass: $84 \pm 17 \mathrm{~g}$ ) were held under permanent dim light in well-aerated water at $0 \pm 0.5^{\circ} \mathrm{C}$. The fish appeared to have been feeding well prior to capture but they were starved for 8 days before experimentation. Experiments were performed aboard the research vessel Polarstern during the austral summer of 1996-7. North Sea eelpout Zoarces viviparus (mass: $53 \pm 17 \mathrm{~g}$ ) were caught off the German North Sea coast and kept for at least 2 months in well aerated water at $3 \pm 1{ }^{\circ} \mathrm{C}$ (coldacclimated) or $12 \pm 1{ }^{\circ} \mathrm{C}$ (warm-acclimated) under a $12 \mathrm{~h}: 12 \mathrm{~h}$ light:dark regime. Ad libitum feeding with shrimps was terminated 8 days prior to experimentation. Pregnant females were not used in this study.

\section{Measurement of standard metabolic rate}

The rate of oxygen uptake in the absence of internal (digestion) or external activity and stress is often referred to as standard metabolic rate (SMR). Zoarcids have an extremely low activity level and spent hours each day just resting on the bottom of their fish container (I. Hardewig, personal observation). The animals were kept in darkened respirometer chambers during measurements in order to minimise visual disturbances. Since oxygen consumption is known to rise following a meal (specific dynamic action, SDA), all fish were starved for at least 8 days prior to the measurement of oxygen consumption. It takes up to 1 week for Antarctic fish to completely digest a meal (Ekau, 1988). This is confirmed by the fact that we did not find any faeces inside the respirometer after a measurement. In the respirometer chambers the fish were shielded from visual disturbances.

SMR of Antarctic eelpout was measured in an intermittentflow respirometer, equipped with six parallel fish chambers. An automated system kept air saturation of the water inside the respirometer at levels above $80 \%$. Even though sea water had been filtered $(0.2 \mu \mathrm{m}$ filter $)$ before use, preliminary experiments showed that blank oxygen consumption could account for up to $50 \%$ of total oxygen consumption. The blank rate was reduced to approximately $3 \%$ of total $\mathrm{O}_{2}$ uptake by the addition of an antibiotic $\left(0.13 \mathrm{mg} \mathrm{l}^{-1}\right.$ Cotrimoxazol $)$. Initial measurements at $0{ }^{\circ} \mathrm{C}$ showed that the antibiotic itself had no effect on the metabolic rate of $P$. brachycephalum. The blank rate was determined each day and subtracted from total oxygen consumption rates. Fish were allowed to acclimate to the experimental conditions at $0{ }^{\circ} \mathrm{C}$ for at least $24 \mathrm{~h}$, which is more than adequate for Antarctic fish (Morris and North, 1984). The first measurement of oxygen consumption was carried out on day 2 at $0 \pm 0.5^{\circ} \mathrm{C}$. The water temperature was raised overnight (by $1{ }^{\circ} \mathrm{C}$ per night) and oxygen consumption was determined during daytime after each temperature step. The temperature was increased to $10^{\circ} \mathrm{C}$ over a 12-day experiment. After $10 \mathrm{~h}$ at $10^{\circ} \mathrm{C}$ the experiment had to be terminated without measuring oxygen consumption since the animals lost balance, indicating that a critical temperature threshold had been reached.

Experiments with Zoarces viviparus were conducted using flow-through respirometry. The inflowing water was $100 \%$ airsaturated, whereas the outflowing water was kept at levels above $80 \%$ air saturation. Measurements were corrected for 
blank oxygen depletion (below 5\% of total oxygen consumption). Animals were acclimated to the experimental conditions for $72 \mathrm{~h}$. The water temperature was raised by $3{ }^{\circ} \mathrm{C}$ each night and oxygen uptake was measured during daytime at $3,6,9,12,15,18,21$ and $24 \pm 0.5^{\circ} \mathrm{C}$. Measurements with warm-acclimated animals were started at $12 \pm 0.5^{\circ} \mathrm{C}$ and additional measurements were performed at 9, 6, 3 and $0 \pm 0.5^{\circ} \mathrm{C}$ or at $15,18,21$ and $24 \pm 0.5^{\circ} \mathrm{C}$. Different rates of temperature increase $\left(1^{\circ} \mathrm{C}\right.$ per night versus $3{ }^{\circ} \mathrm{C}$ per night) were used for $P$. brachycephalum and $Z$. viviparus, respectively, taking into account the different ranges of temperature tolerated by these species $\left(0-10^{\circ} \mathrm{C}\right.$ versus $\left.0-24^{\circ} \mathrm{C}\right)$.

\section{Incubations}

Individual $Z$. viviparus were put in darkened 31 containers filled with aerated water at $3 \pm 1^{\circ} \mathrm{C}$. About half of the water volume was replaced by fresh water of the same temperature on a daily basis. The water temperature was gradually increased at a rate of $3{ }^{\circ} \mathrm{C}$ per day. Initial trials did not show any physiological disturbances at water temperatures up to $18^{\circ} \mathrm{C}$. Fish were killed in three groups: after $24 \mathrm{~h}$ at $21^{\circ} \mathrm{C}$ $(N=5)$, after $24 \mathrm{~h}$ at $24^{\circ} \mathrm{C}(N=4)$ and after $72 \mathrm{~h}$ at $24^{\circ} \mathrm{C}(N=4)$. Control fish $(N=5)$ were killed after 3 days at $3{ }^{\circ} \mathrm{C}$. Antarctic eelpout, $P$. brachycephalum, were treated in a similar way. Water temperature was increased at a rate of $1^{\circ} \mathrm{C}$ per day. Fish were killed after $24 \mathrm{~h}$ at $0,3,6$ and $9^{\circ} \mathrm{C}(N=5$ for each group). The fish incubated at $10^{\circ} \mathrm{C}$ were sampled after $10 \mathrm{~h}(N=5)$. Fish were anaesthetised by slowly adding a concentrated MS-222 solution to the individual animal chamber, until a final concentration of $0.25 \mathrm{~g} \mathrm{l}^{-1}$ was reached. As soon as full anaesthesia set in, the fish was quickly placed on ice, epaxial white muscle, blood, liver and heart samples were excised and the animal was killed by decapitation. Tissue samples were freeze-clamped immediately and stored in liquid nitrogen. Plasma samples were kept at $-80^{\circ} \mathrm{C}$ until analysis.

\section{Tissue preparation and analysis}

Tissue samples were prepared as described by Hardewig et al. (1998). Concentrations of lactate, glucose, succinate, creatine phosphate, creatine and ATP were determined enzymatically according to Bergmeyer (1985). Intracellular $\mathrm{pH}$ and $\mathrm{PCO}_{2}$ in white muscle tissue were determined according to Pörtner et al. (1990). For the determination of in vivo $\mathrm{pH}_{\mathrm{i}}$ values at different incubation temperatures, tissue samples were ground to a fine powder under liquid nitrogen and suspended in a solution containing $150 \mathrm{mmoll}^{-1} \mathrm{KF}$ and $6 \mathrm{mmoll}^{-1} \mathrm{Na}_{2} \mathrm{NTA}$ (nitrilotriacetic acid). Both KF and NTA serve as inhibitors, largely reducing the rate of those metabolic reactions that might influence homogenate $\mathrm{pH}$. After brief centrifugation $(<15 \mathrm{~s})$, the $\mathrm{pH}$ of the supernatant was measured with a thermostatted capillary pH electrode (G297/G2, Radiometer Copenhagen, Denmark), which had been calibrated at the particular incubation temperature of the fish. Total $\mathrm{CO}_{2}$ content of the homogenates were measured in triplicate by gas chromatography (100 AGC, Hach Carle, Loveland CO, USA). Calibration was performed by using 1 and $2 \mathrm{mmoll}^{-1}$ sodium bicarbonate as standard solutions.

\section{Calculations and statistics}

Oxygen consumption data were normalised for a $100 \mathrm{~g}$ fish. The size range of our experimental animals was much too small to determine a mass exponent $b$. Therefore, we used $b=0.81$, an average value that Beamish (1963) had determined for marine fish. Intracellular $\mathrm{PCO}_{2}$ and bicarbonate concentrations were evaluated applying the HendersonHasselbalch equation (for more details see Pörtner et al., 1990). Levels of free ADP and AMP were calculated on the basis of the equilibrium of creatine kinase (CK) and myokinase (MK). Values for $K_{\text {eqCK }}$ and $K_{\text {eqMK }}$ at the appropriate temperatures were taken from Teague and Dobson (1992) and Tewari et al. (1991). The Gibbs free energy change of ATP hydrolysis $(\Delta G / \Delta \xi)$ was calculated on the basis of the determined metabolite concentrations and $\mathrm{pH}_{\mathrm{i}}$ values, considering the $\mathrm{pH}$ dependent concentrations of the reactive species of ATP, ADP and $\mathrm{P}_{\mathrm{i}}$ at a constant free cellular $\mathrm{Mg}^{2+}$ concentration of $1 \mathrm{mmoll}^{-1}$, as outlined by Pörtner et al. (1996). Free inorganic phosphate was assumed to be $1 \mathrm{mmol}^{-1}$ in resting animals (G. van den Thillart, personal communication). Data were checked for outliers beyond the $95 \%$ confidence limit using Nalimov's test (Noack, 1980). Statistical significance was tested at the $P \leqslant 0.05$ level using analysis of variance (ANOVA) and the post-hoc Student-Newman-Keuls test for independent samples. Unless stated differently, data are given as means \pm S.D.

\section{Results \\ Respirometry}

Oxygen consumption rates of cold-adapted Pachycara brachycephalum $\left(0^{\circ} \mathrm{C}\right)$, as well as cold- $\left(3^{\circ} \mathrm{C}\right)$ and warm$\left(12^{\circ} \mathrm{C}\right)$ acclimated Zoarces viviparus are presented in Fig. $1 \mathrm{~A}$. Cold-acclimated $Z$. viviparus and cold-adapted $P$. brachycephalum had similar standard metabolic rates (SMR) in the low temperature range, which were significantly higher than those of warm-acclimated North Sea eelpout at low temperatures. Oxygen consumption of $P$. brachycephalum showed a more rapid increase with temperature than SMR of Z. viviparus. Arrhenius plots of SMR of all three experimental groups revealed linear slopes and no break over the investigated temperature range (Fig. 1B). The slopes of the three plots (which were significantly different from each other, $P<0.05)$ correlate with the Arrhenius activation energy for oxygen consumption. Accordingly, the activation energy was highest for Antarctic eelpout $\left(99.4 \pm 5.9 \mathrm{~kJ} \mathrm{~mol}^{-1}\right.$, mean \pm S.E.M.), intermediate for warm acclimated $Z$. viviparus $\left(82.9 \pm 4.9 \mathrm{~kJ} \mathrm{~mol}^{-1}\right)$ and lowest for cold-acclimated eelpout $\left(55.5 \pm 3.2 \mathrm{~kJ} \mathrm{~mol}^{-1}\right) . Q_{10}$ values of the oxygen consumption can be ranked in the same declining order: 5.2, 3.0 and 2.4 for $P$. brachycephalum, and for warm- and cold-acclimated $Z$. viviparus, respectively. 

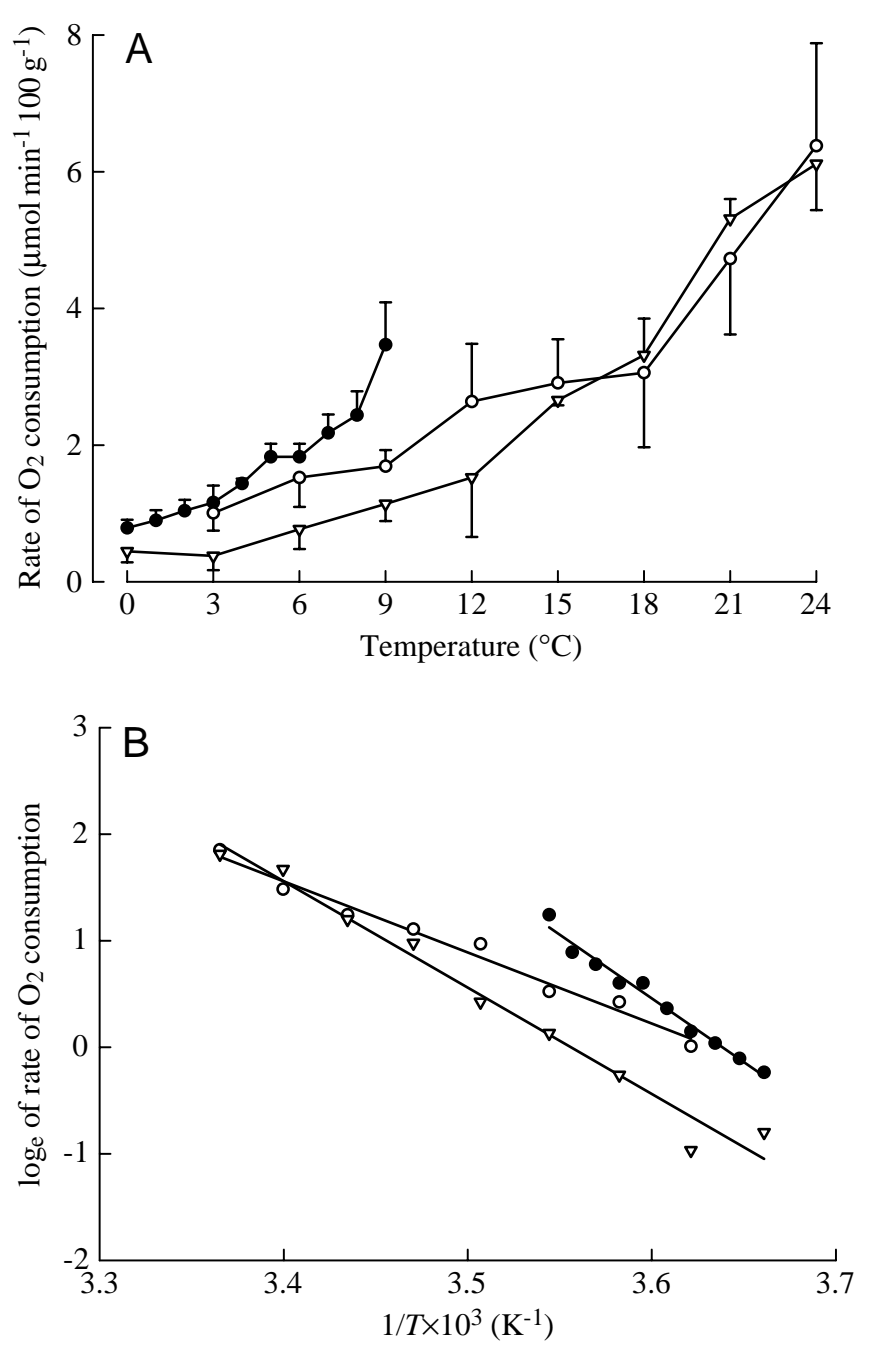

Fig. 1. (A) Changes in oxygen consumption with temperature in cold-adapted Pachycara brachycephalum. $\left(0^{\circ} \mathrm{C}\right.$; filled circles $)$ and in cold- $\left(3{ }^{\circ} \mathrm{C}\right.$; open circles $)$ and warm- $\left(12^{\circ} \mathrm{C}\right.$; open triangles $)$ acclimated Zoarces viviparus. Values are means \pm S.D., $N=5$. (B) Arrhenius plot of oxygen consumption; data adapted from A. The slopes of the lines are significantly different $(P \leqslant 0.05)$.

\section{Intracellular $\mathrm{pH}$ and metabolites}

Temperature incubation experiments were carried out to determine possible disturbances in $\mathrm{pH}$ regulation and cellular energetics at critically high temperatures. Pilot studies with $Z$. viviparus showed that at temperatures between $3{ }^{\circ} \mathrm{C}$ and $18^{\circ} \mathrm{C}$ all measured parameters remained at the respective control levels. Therefore, we investigated temperatures beyond that range in the present study.

All experimental groups in this study started out with $N=5$, but due to mortality during the experiment, the groups of common eelpout exposed to $24{ }^{\circ} \mathrm{C}$ for $24 \mathrm{~h}$ and for $72 \mathrm{~h}$ group ended up with only $N=4$ each. There were no mortalities among the Antarctic eelpouts.

The intracellular $\mathrm{pH}$ of the white musculature was similar in both species when compared in the low temperature range. The $\mathrm{pH}_{\mathrm{i}}$ of $7.43 \pm 0.06$ determined in $P$. brachycephalum at $0{ }^{\circ} \mathrm{C}$ is

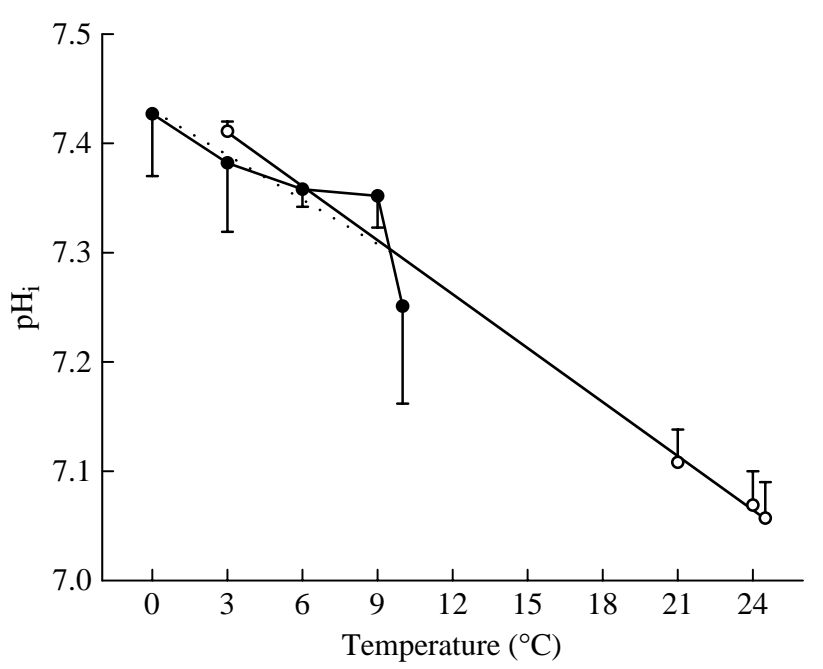

Fig. 2. Relationship between white muscle intracellular $\mathrm{pH}$ and ambient temperature in cold-acclimated common eelpout Zoarces viviparus (open circles) and Antarctic eelpout Pachycara brachycephalum (filled circles). Values are means \pm S.D., $N=4-5$. First order regression lines were calculated between $3{ }^{\circ} \mathrm{C}$ and $24^{\circ} \mathrm{C}$ for Z. viviparus (solid line; $\Delta \mathrm{pH} / \Delta T=-0.016 \mathrm{pH}$ units per ${ }^{\circ} \mathrm{C}$ ) and between $0{ }^{\circ} \mathrm{C}$ and $3{ }^{\circ} \mathrm{C}$ for $P$. brachycephalum (dotted line; $\Delta \mathrm{pH} / \Delta T=-0.015 \mathrm{pH}$ units per $\left.{ }^{\circ} \mathrm{C}\right)$.

very similar to the value of $7.42 \pm 0.03$ determined by in vivo ${ }^{31} \mathrm{P}-\mathrm{NMR}$ measurements in the same species at $0{ }^{\circ} \mathrm{C}(\mathrm{C}$. Bock, F. J. Sartoris, H. O. Pörtner, unpublished results), indicating that anaesthesia and handling did not affect $\mathrm{pH}_{\mathrm{i}}$ in our study. ${ }^{31} \mathrm{P}-\mathrm{NMR}$ measurements of the white muscle $\mathrm{pH}$ of the Antarctic notothenioid Harpagifer antarcticus determined a value of $7.36 \pm 0.07$ at $1{ }^{\circ} \mathrm{C}$ (Moerland and Egginton, 1998), which is in good agreement with our data. North Sea eelpout white muscle $\mathrm{pH}_{\mathrm{i}}$ decreased with increasing temperature at a rate of $-0.016 \mathrm{pH}$ units per ${ }^{\circ} \mathrm{C}$, and thus followed alphastat regulation (Reeves, 1972; Fig. 2). This is identical to our earlier published rate for warm-acclimated $Z$. viviparus (van Dijk et al., 1997). The temperature window over which alphastat regulation takes place is much smaller in polar than in temperate zone species (see Discussion and Pörtner et al., 1998). In $P$. brachycephalum white muscle, $\Delta \mathrm{pH} / \Delta T$ was $-0.015 \mathrm{pH}$ units per ${ }^{\circ} \mathrm{C}$ between $0{ }^{\circ} \mathrm{C}$ and $3{ }^{\circ} \mathrm{C}$ (Fig. 2). Beyond this temperature range, $\mathrm{pH}_{\mathrm{i}}$ was nearly constant with increasing temperature before it suddenly showed a remarkable drop by $0.1 \mathrm{pH}$ units between $9^{\circ} \mathrm{C}$ and $10^{\circ} \mathrm{C}$. Other acid-base parameters in the white muscle of Antarctic eelpout were not affected by temperature. No significant changes with temperature were observed in total $\mathrm{CO}_{2}$ content $\left(C_{\mathrm{CO}_{2}}\right)$, bicarbonate concentration $\left(\left[\mathrm{HCO}_{3}{ }^{-}\right]\right)$or $\mathrm{CO}_{2}$ partial pressure $\left(P_{\mathrm{CO}_{2}}\right.$; Table 1).

The increase in water temperature did not have any dramatic effects on the energy status of the white musculature in either species. In the white musculature of common eelpout we found no significant changes with rising temperature in the concentrations of phosphocreatine (PCr) and creatine (Cr), but 


\section{Heat-induced disturbances in fish 3615}

Table 1. Acid-base parameters in the white muscle of cold-adapted $\left(0^{\circ} \mathrm{C}\right)$ Antarctic eelpout, Pachycara brachycephalum, after a gradual temperature increase

\begin{tabular}{lcccccc}
\hline & \multicolumn{5}{c}{ Temperature $\left({ }^{\circ} \mathrm{C}\right)$} \\
\cline { 2 - 6 } & 0 & 3 & 6 & 9 & 10 \\
\hline$C_{\mathrm{CO}_{2}}$ & $4.1 \pm 1.6$ & $3.3 \pm 1.4$ & $2.70 \pm 0.31$ & $3.2 \pm 1.3$ & $3.63 \pm 0.72$ \\
{$\left[\mathrm{HCO}_{3}{ }^{-}\right]$} & $3.8 \pm 1.5$ & $3.0 \pm 1.4$ & $2.52 \pm 0.28$ & $2.9 \pm 1.2$ & $3.13 \pm 0.23$ \\
$P_{\mathrm{CO}_{2}}$ & $0.44 \pm 0.16$ & $0.333 \pm 0.049$ & $0.369 \pm 0.032$ & $0.44 \pm 0.18$ & $0.59 \pm 0.11$
\end{tabular}

Temperature was increased by $1{ }^{\circ} \mathrm{C}$ per night.

Total $\mathrm{CO}_{2}\left(C_{\mathrm{CO}_{2}}\right)$ and $\mathrm{HCO}_{3}{ }^{-}$concentrations are given as mmoll ${ }^{-1}$ and the partial pressure of $\mathrm{CO}_{2}\left(P_{\mathrm{CO}_{2}}\right)$ as $\mathrm{kPa}$. For intracellular pH of white muscle see Fig. 2.

Values are means \pm S.D., $N=5$.

*Significant difference from control fish kept at $0{ }^{\circ} \mathrm{C}(P \leqslant 0.05)$.

Table 2. Metabolic and energetic parameters in cold-acclimated $\left(3^{\circ} \mathrm{C}\right)$ common eelpout, Zoarces viviparus, after a gradual temperature increase

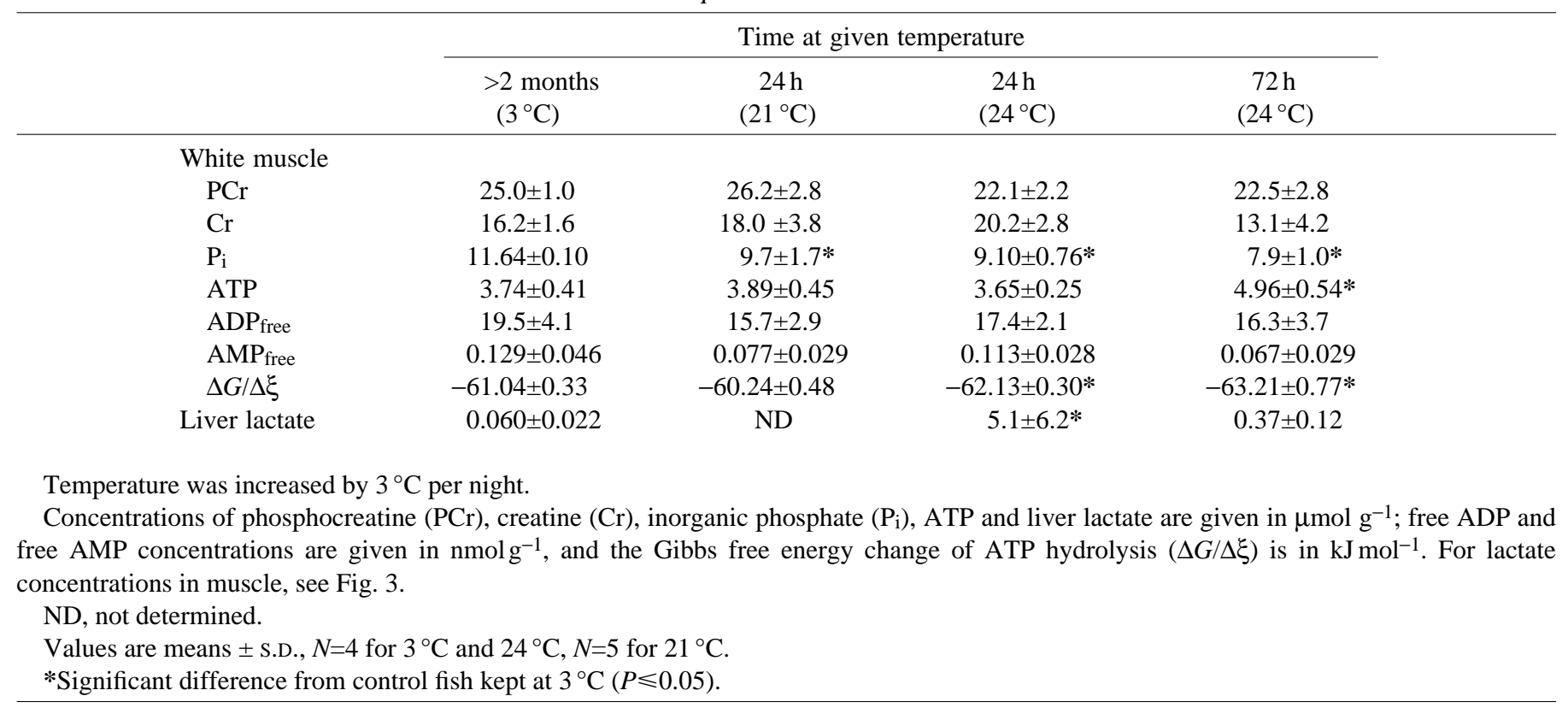

there was a trend towards lower levels of $\mathrm{PCr}$ at higher temperatures and a significant drop in inorganic phosphate $\left(\mathrm{P}_{\mathrm{i}}\right)$ in all three experimental groups $\left(24 \mathrm{~h}\right.$ at $21^{\circ} \mathrm{C}, 24 \mathrm{~h}$ at $24^{\circ} \mathrm{C}$ and $72 \mathrm{~h}$ at $24^{\circ} \mathrm{C}$; Table 2 ). There were no significant changes in white muscle ATP, free ADP or free AMP concentrations with temperature, except for an increased level of ATP after $72 \mathrm{~h}$ at $24^{\circ} \mathrm{C}$ (Table 2). The Gibbs free energy change of ATP hydrolysis $(\Delta G / \Delta \xi)$ was significantly increased after $24 \mathrm{~h}$ and $72 \mathrm{~h}$ at $24^{\circ} \mathrm{C}$ (Table 2). Heat exposure had no significant influence on $\mathrm{PCr}, \mathrm{Cr}$, free ADP and free AMP contents of $P$. brachycephalum white muscle (Table 3 ). In contrast to $Z$. viviparus, $\mathrm{P}_{\mathrm{i}}$ levels were elevated at higher temperatures (Table 3). ATP content also tended to be higher at elevated temperatures, and this difference was significant at $6{ }^{\circ} \mathrm{C}$ and $10^{\circ} \mathrm{C}$ (Table 3). $\Delta G / \Delta \xi$ remained at the control level for the entire temperature range investigated (Table 3 ).

Lactate is the major anaerobic endproduct in fish. Therefore, its concentration was expected to rise at temperatures above the critical threshold. In Z. viviparus, white muscle lactate levels started to rise at $21^{\circ} \mathrm{C}$ and increased significantly from $1.1 \pm 0.1$ in controls to $3.1 \pm 1.2 \mu \mathrm{mol}^{-1} \mathrm{~g}^{-1}$ after $24 \mathrm{~h}$ at $24^{\circ} \mathrm{C}$ (Fig. 3). Surprisingly, the rise in lactate concentration was reversed after $72 \mathrm{~h}$ at $24^{\circ} \mathrm{C}$. In $P$. brachycephalum, muscle lactate remained at control levels at temperatures up to $9^{\circ} \mathrm{C}$, but displayed a notable rise at $10^{\circ} \mathrm{C}$ (Fig. 3). Changes in lactate levels in liver tissue showed the same pattern as in white muscle in both species (Tables 2, 3).

Succinate, an additional anaerobic endproduct observed in fish tissues, was determined in heart, liver and white muscle. Succinate is part of the citric acid cycle and its accumulation indicates mitochondrial anaerobiosis (Grieshaber et al., 1994). In common eelpout, a transient increase of succinate levels was observed in heart and white muscle, similar to changes seen in white muscle lactate (Fig. 4). These changes were not significant. In Antarctic eelpout, the succinate concentrations of heart and white muscle showed a slight but insignificant elevation at $10^{\circ} \mathrm{C}$ (Fig. 4). In both eelpout species, however, we found a significant heat-induced accumulation of succinate 


\section{P. L. M. VAN DIJK AND OTHERS}

Table 3. Metabolic and energetic parameters in cold-adapted $\left(0^{\circ} \mathrm{C}\right)$ Antarctic eelpout, Pachycara brachycephalum, after a gradual temperature increase

\begin{tabular}{|c|c|c|c|c|c|}
\hline & \multicolumn{5}{|c|}{ Temperature $\left({ }^{\circ} \mathrm{C}\right)$} \\
\hline & 0 & 3 & 6 & 9 & 10 \\
\hline \multicolumn{6}{|l|}{ White muscle } \\
\hline $\mathrm{PCr}$ & $23.8 \pm 3.0$ & $21.8 \pm 2.1$ & $22.5 \pm 1.8$ & $26.2 \pm 2.7$ & $20.8 \pm 1.7$ \\
\hline $\mathrm{Cr}$ & $15.5 \pm 2.3$ & $13.1 \pm 4.3$ & $13.9 \pm 1.5$ & $11.7 \pm 2.6$ & $18.1 \pm 3.1$ \\
\hline $\mathrm{P}_{\mathrm{i}}$ & $10.8 \pm 1.3$ & $10.7 \pm 2.1$ & $12.8 \pm 1.1$ & $11.1 \pm 2.6$ & $14.3 \pm 1.7 *$ \\
\hline ATP & $3.44 \pm 0.71$ & $3.99 \pm 0.69$ & $4.43 \pm 0.32 *$ & $4.13 \pm 0.14$ & $4.34 \pm 0.40 *$ \\
\hline $\mathrm{ADP}_{\text {free }}$ & $18.8 \pm 2.8$ & $15.7 \pm 5.1$ & $19.9 \pm 2.6$ & $14.1 \pm 4.2$ & $23.5 \pm 3.1$ \\
\hline $\mathrm{AMP}_{\text {free }}$ & $0.122 \pm 0.034$ & $0.088 \pm 0.044$ & $0.116 \pm 0.033$ & $0.066 \pm 0.038$ & $0.161 \pm 0.037$ \\
\hline$\Delta G / \Delta \xi$ & $-60.98 \pm 0.81$ & $-61.28 \pm 0.77$ & $-61.63 \pm 0.38$ & $-62.10 \pm 0.90$ & $-60.97 \pm 0.18$ \\
\hline Liver lactate & $0.053 \pm 0.016$ & ND & ND & ND & $0.132 \pm 0.081$ \\
\hline $\begin{array}{l}\text { Temperature was increase } \\
\text { For units, see Table } 2 . \\
\text { For lactate concentrations } \\
\text { ND, not determined. } \\
\text { Values are means } \pm \text { S.D., } I \\
* \text { Significant difference fro }\end{array}$ & $\begin{array}{l}\text { y } 1{ }^{\circ} \mathrm{C} \text { per night. } \\
\text { muscle, see Fig. } \\
\text { control fish kept }\end{array}$ & ${ }^{\circ} \mathrm{C}(P \leqslant 0.05)$ & & & \\
\hline
\end{tabular}

in liver (Fig. 4). Liver succinate levels in Antarctic eelpout were almost one order of magnitude lower than in coldacclimated North Sea eelpout. The factorial change during heat stress, however, was similar in both species. In consequence, liver succinate turned out to be the most useful and unequivocal indicator for the upper critical temperature in Zoarcidae. Plasma glucose, a general indicator of stress, was not affected by rising temperature in common eelpout, whereas

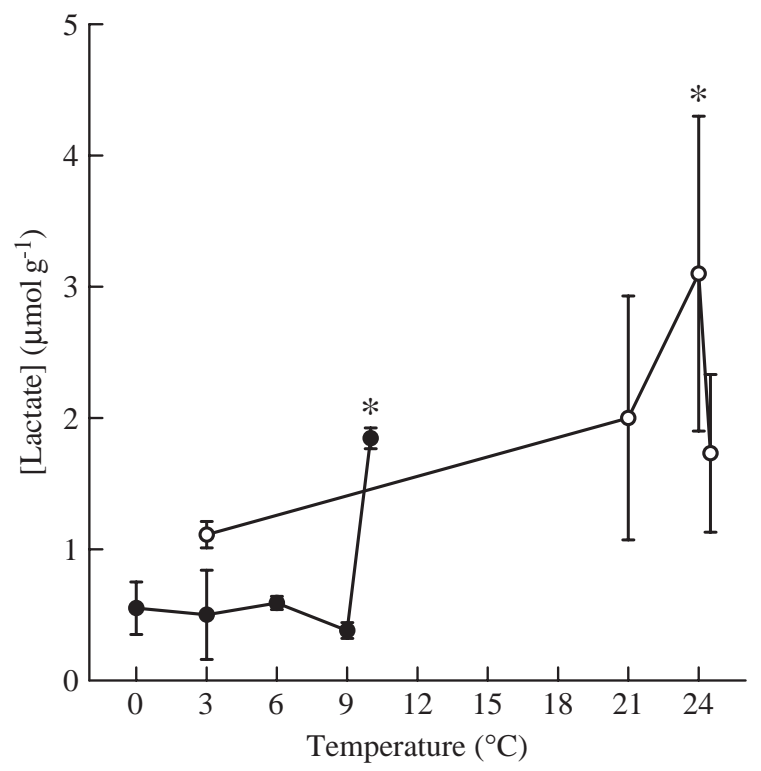

Fig. 3. Lactate concentration in the white muscle of common eelpout Zoarces viviparus (open circles), and Antarctic eelpout Pachycara brachycephalum (filled circles), after a gradual temperature increase by $3{ }^{\circ} \mathrm{C}$ and $1{ }^{\circ} \mathrm{C}$ per night, respectively. Values are means \pm S.D., $N=4-5$. *Significantly different from cold-acclimated/adapted control fish $(P \leqslant 0.05)$. it increased drastically at $9{ }^{\circ} \mathrm{C}$ and $10^{\circ} \mathrm{C}$ in its Antarctic counterpart (Fig. 5).

\section{Discussion}

Our study has shown that $Z$. viviparus is much more tolerant to heat than the Antarctic eelpout $P$. brachycephalum. The critical temperature threshold $\left(T \mathrm{c}_{\mathrm{II}}\right)$ was found to be between $21{ }^{\circ} \mathrm{C}$ and $24^{\circ} \mathrm{C}$ in $Z$. viviparus and between $9{ }^{\circ} \mathrm{C}$ and $10^{\circ} \mathrm{C}$ in $P$. brachycephalum. While the Antarctic species never encounters these critically high temperatures in its habitat, $Z$. viviparus may be naturally exposed to stressful temperatures, especially at its southern distribution limit at the latitude of northern France (Andriashev, 1986), where maximum summer water temperatures can exceed $20^{\circ} \mathrm{C}$. Further south at the Atlantic coast, where $Z$. viviparus no longer occurs, water temperatures reach even higher values due to the warm Gulf Stream. Thus, there is a correlation between the maximum temperature $Z$. viviparus can tolerate and the maximum temperature this species is exposed to at its southern distribution limit. Therefore, it can be anticipated that changes in summer maximum temperatures due to global warming would cause a shift in the distribution of this species.

Investigating the influence of critically high temperatures on the physiology of the two eelpout species we address three interrelated aspects, namely metabolic rate, acid-base regulation and energy metabolism.

\section{Metabolic rate}

Measured oxygen consumption rates can be considered to be standard metabolic rate (SMR), since zoarcids are active only during the first hours inside the respirometer chamber. Sluggish Antarctic fish such as zoarcids can remain motionless for periods of up to $22 \mathrm{~h}$ (Zimmermann and Hubold, 1998). Our own observations, as well as those of Wohlschlag (1963), lead 

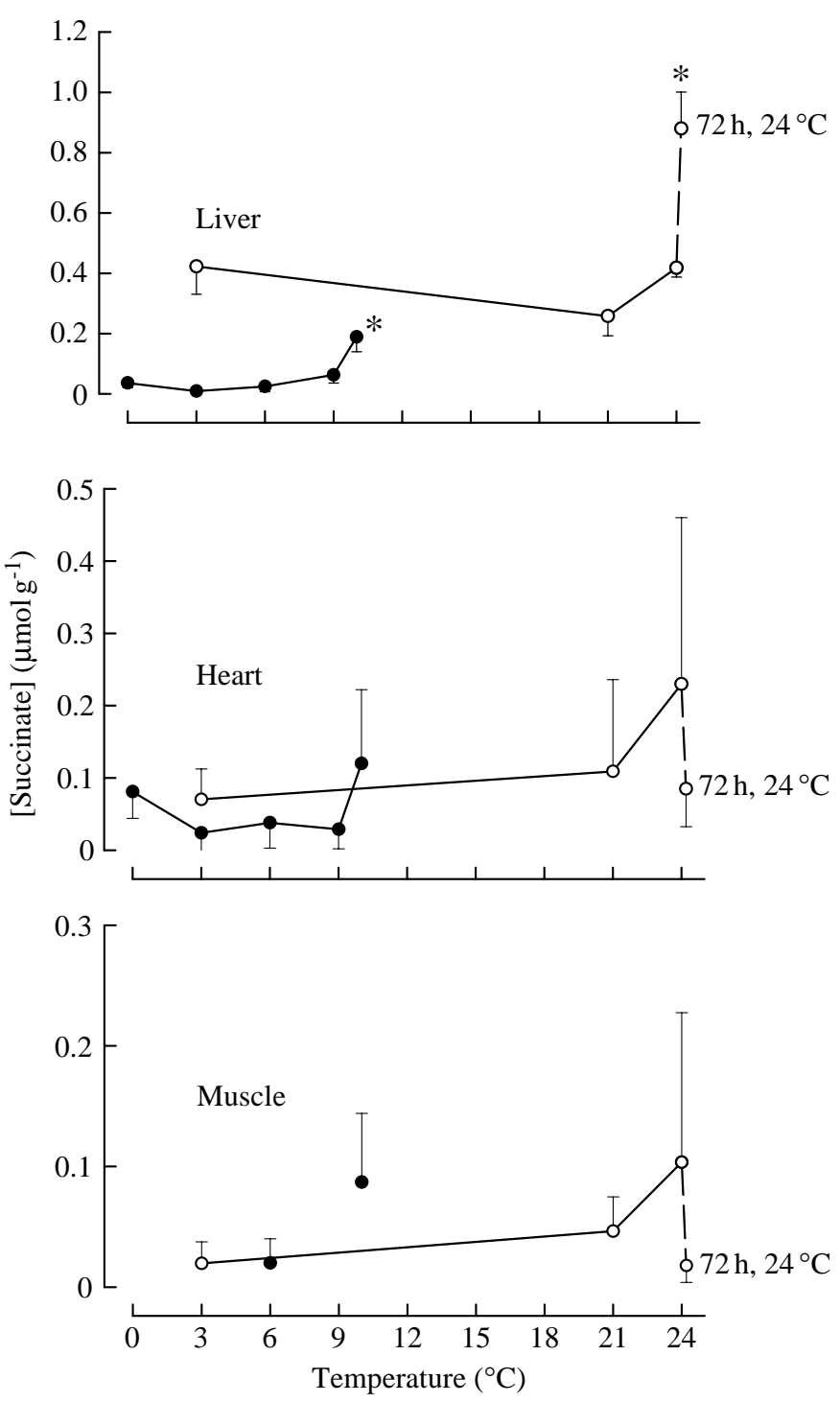

Fig. 4. Succinate concentration in liver, heart and white muscle of common eelpout Zoarces viviparus (open circles), and in liver and heart of Antarctic eelpout Pachycara brachycephalum (filled circles), after a gradual temperature increase by $3^{\circ} \mathrm{C}$ and $1{ }^{\circ} \mathrm{C}$ per night, respectively. Data are means \pm S.D. $(N=4-5)$, except for heart succinate levels after $24 \mathrm{~h}$ at $24^{\circ} \mathrm{C}$ in common eelpout (mean \pm range; $N=2$ ). Succinate white muscle concentration of Antarctic eelpout has been determined in only two groups (no significant difference). *Significant difference from cold-acclimated/adapted fish $(P \leqslant 0.05)$.

to the conclusion that eelpout show extremely little spontaneous activity. Oxygen consumption measurements for Zoarces viviparus have been performed in a flow-through respirometer, whereas those for $P$. brachycephalum were conducted with an intermittent-flow respirometer. These two different ways of respirometry are expected to lead to similar results, as confirmed by von Dorrien (1993) in a study on Antarctic fish of the genus Pogonophryne.

Oxygen consumption rates of the investigated species were compared in order to reveal whether adaptive differences in

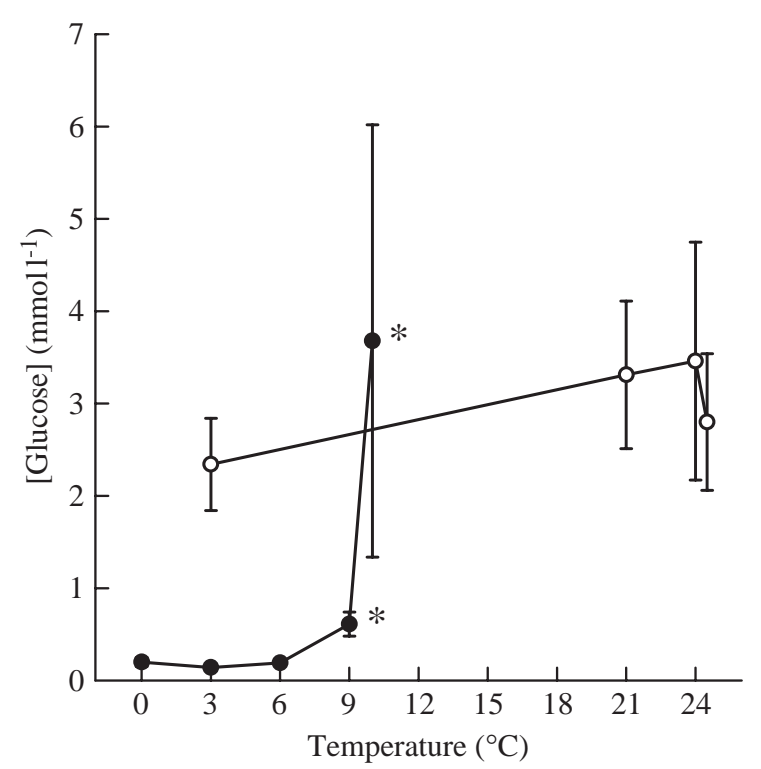

Fig. 5. Plasma glucose concentration in common eelpout Zoarces viviparus (open circles) and Antarctic eelpout Pachycara brachycephalum (filled circles) after a gradual temperature increase of $3{ }^{\circ} \mathrm{C}$ and $1{ }^{\circ} \mathrm{C}$ per night, respectively. Values are means \pm S.D., $N=$ 4-5. *Significant difference from cold-acclimated/adapted control fish $(P \leqslant 0.05)$.

metabolic rates occur (metabolic cold adaptation), which may relate to differences in thermal tolerance (see below). The concept of metabolic cold adaptation (MCA) is one of the most controversial ideas in Antarctic fish physiology (Holeton, 1974; Torres and Somero, 1988a,b). Wohlschlag's original definition states: 'that polar fishes are cold-adapted implies that their metabolism is higher at low temperatures than the metabolism is for fish adapted to higher temperatures but acclimatised to similar low temperatures' (Wohlschlag, 1964). There has been much discussion about whether or not polar fish show MCA (Clarke, 1991), but to our knowledge nobody so far has actually measured the presence or absence of MCA according to Wohlschlag's definition. In all studies concerning MCA, metabolic rate of Antarctic species has been compared to metabolic rates of warm-acclimated temperate or tropical species extrapolated to polar temperatures (Wohlschlag, 1963; Torres and Somero, 1988a,b; Johnston et al., 1991). Only Wells (1987) tried to minimise the problems involved when extrapolating data over a broad temperature range. $\mathrm{He}$ compared oxygen consumption rates of Antarctic fish at $-1.5^{\circ} \mathrm{C}$ to rates of the less stenothermal Arctic cod acclimated to temperatures between 0 and $10^{\circ} \mathrm{C}$. His data provided evidence for MCA.

In general, comparisons of metabolic rate of polar and nonpolar species are not without problems. To avoid 'apples to oranges' comparisons, the used fish species have to be as similar as possible in lifestyle, feeding strategy, locomotory ability, body size and dietary state. Ideally, the species should also be from the same family. To our knowledge the present study is the first investigation where these objectives are met 


\section{P. L. M. VAN DIJK AND OTHERS}

and where temperate fish have been acclimated to similarly low temperatures as the Antarctic species to allow a direct comparison of metabolic rates. We measured the temperature dependence of oxygen consumption in two related species, cold- and warm-acclimated temperate eelpout (Zoarces viviparus) and of cold-adapted Antarctic eelpout (Pachycara brachycephalum). These fish species are very similar in lifestyle. Both are carnivorous sit-and-wait predators that are mainly inactive. The difference in depth occurrence between these two species probably has no impact on their metabolic rate. For benthic species it was shown that there is no decrease in metabolic rate with increasing minimal depth of occurrence other than those due to temperature differences (Childress, 1995).

Our oxygen uptake measurements suggest that cold acclimation as well as cold adaptation lead to a similar rise in oxygen consumption, compared to warm-acclimated fish. This reflects some degree of cold compensation in metabolic rate. Still, we did not find any evidence for MCA (in sensu Wohlschlag) in zoarcids, confirming Wohlschlag's own conclusion that zoarcids 'appear not to be highly cold-adapted' (Wohlschlag, 1963). Nevertheless, a compensatory rise in metabolic rate does occur in both the cold-acclimated and the cold-adapted group, leading us also to ask for the mechanisms and trade-offs behind.

The $Q_{10}$ values of oxygen consumption in common eelpout (2.4 for cold- and 3.0 for warm-acclimated Z viviparus, determined between $3-24^{\circ} \mathrm{C}$ and $0-24{ }^{\circ} \mathrm{C}$, respectively) were lower than in Antarctic eelpout, which has a relatively high $Q_{10}$ of 5.2 (determined between $0{ }^{\circ} \mathrm{C}$ and $9{ }^{\circ} \mathrm{C}$ ). The Arrhenius activation energy for oxygen consumption was $83 \mathrm{~kJ} \mathrm{~mol}^{-1}$ for warm-acclimated and $53 \mathrm{~kJ} \mathrm{~mol}^{-1}$ for cold-acclimated $Z$. viviparus. These values are in the range of those determined for other fish species. Using the data of Johnston and coworkers (1991), we have calculated the activation energy for P. forsteri as $72 \mathrm{~kJ} \mathrm{~mol}^{-1}$; for $P$. arcatus, $54 \mathrm{~kJ} \mathrm{~mol}^{-1}$; for $M$. scorpius, $61 \mathrm{~kJ} \mathrm{~mol}^{-1}$; and for $N$. neglecta, $68 \mathrm{~kJ} \mathrm{~mol}^{-1}$. Again, Antarctic eelpout $\left(99 \mathrm{~kJ} \mathrm{~mol}^{-1}\right)$ has a value that is slightly beyond the ordinary range. This indicates that the metabolic rate of $P$. brachycephalum increases more strongly with rising temperature and that their SMR is more susceptible to temperature changes than those of other fish. The question arises as to whether the sensitivity of metabolic rate to rising temperatures relates to the thermal sensitivity of other physiological processes.

\section{Acid-base regulation}

According to Reeves (1972), poikilotherms regulate the $\mathrm{pH}$ of their body fluids such that the degree of protonation $(\alpha)$ of imidazole groups is maintained despite changes in body temperature. This so-called alphastat process is presented as an important prerequisite to maintain the structural integrity of proteins despite temperature changes (Hochachka and Somero, 1984). In a recent paper Moerland and Egginton (1998) suggested that alphastat regulation in fish does not occur in the low temperature range. However, they carried out an interspecific comparison (including the Antarctic Notothenioid Harpagifer antarcticus), which may have overlooked the fact that alphastat regulation within a species does occur even at low temperatures: the $\mathrm{pH}_{\mathrm{i}}$ of the white musculature of $\mathrm{Z}$. viviparus follows alphastat regulation between 0 and $24^{\circ} \mathrm{C}$ (see also van Dijk et al., 1997), whereas $P$. brachycephalum regulates $\mathrm{pH}_{\mathrm{i}}$ according to alphastat between 0 and $3^{\circ} \mathrm{C}$. The absolute $\mathrm{pH}$ value for $P$. brachycephalum, however, is lower than expected from the extrapolation of the data for $Z$. viviparus (see Fig. 2), in accordance with the study of Moerland and Egginton (1998).

The temperature range at which alphastat regulation occurs within a species is generally smaller in polar than in temperate animals and is correlated with the thermal tolerance of the organism (Pörtner et al., 1998). In the present investigation, we observed a drastic drop in white muscle intracellular $\mathrm{pH}$ at the critical temperature in Antarctic but not in common eelpout. The marked depression of $\mathrm{pH}_{\mathrm{i}}$ observed in $P$. brachycephalum at $10^{\circ} \mathrm{C}$ can be fully explained by the release of metabolic protons due to the observed lactate formation (the calculation is based on a buffer capacity of 20.3 mequiv $\mathrm{pH}^{-1} \mathrm{~kg}^{-1}$ fresh mass, determined in the white muscle of $Z$. viviparus; van Dijk et al., 1997). In contrast, recent work on Antarctic octopods suggests that an acidosis in excess of metabolic acidification occurs beyond the critical temperature, indicating net base loss and a drastic change in ion distribution (S. Zielinski and H. O. Pörtner, unpublished results).

\section{Energy metabolism}

Control levels of plasma glucose were significantly lower in $P$. brachycephalum $\left(0.20 \pm 0.05 \mathrm{mmoll}^{-1}\right)$ than in common eelpout $\left(2.34 \pm 0.50 \mathrm{mmoll}^{-1}\right)$ or in other Antarctic fish. Cannulated, routinely active $N$. neglecta and $N$. rossii had plasma glucose levels of $1.67 \pm 0.93$ and $14.43 \pm 5.6 \mathrm{mmoll}^{-1}$, respectively (Egginton et al., 1991). While increasing temperatures did not affect glucose levels in Z. viviparus, they caused a steep increase in $P$. brachycephalum. Plasma glucose levels are known to rise in teleosts after various forms of stress, including chronic and acute exposure to extreme temperature (Albrecht, 1982; Kindle and Whitemore, 1986; van Dijk et al., 1993; Staurnes et al., 1994). Both adrenaline and cortisol, wellknown stress hormones, are reported to cause hyperglycaemia in fish, with the importance of each hormone varying among species (Mazeaud et al., 1977; Leach and Taylor, 1980). The possible significance of hyperglycaemia in the maintenance of plasma osmolality, under conditions when the fish lose plasma electrolytes rapidly, has been discussed (McDonald, 1983). It may also indicate the mobilization of liver glycogen stores. $Z$. viviparus does not show heat-induced hyperglycaemia. As a corollary, plasma glucose levels are an indicator for $T \mathrm{c}_{\mathrm{II}}$ in Antarctic, but not in common, eelpout.

Previous work in invertebrates indicates that limited oxygen supply to tissues is involved in setting the limits of thermal tolerance leading to the onset of anaerobic metabolism, especially of the mitochondria (for a review, see Pörtner et al., 1998). Lactate and succinate are both anaerobic endproducts 
in fish. The latter is a direct indicator of mitochondrial anaerobiosis (Grieshaber et al., 1994). In Antarctic eelpout, lactate concentrations of the white muscle remained at control levels between 0 and $9{ }^{\circ} \mathrm{C}$, but $10 \mathrm{~h}$ at $10^{\circ} \mathrm{C}$ caused a clear rise in this parameter. Ryan (1995) reported that in the Antarctic fish Pagothenia borchgrevinki, plasma lactate levels remained at control levels $\left(0.4 \mathrm{mmol} \mathrm{l}^{-1}\right)$ during 2 days at $5^{\circ} \mathrm{C}$, but were significantly elevated at $8^{\circ} \mathrm{C}\left(1-2 \mathrm{mmol}^{-1}\right)$. This may indicate that the upper critical temperature of this Notothenioid is reached at temperatures between $5^{\circ}$ and $8^{\circ} \mathrm{C}$. In a different study the incipient upper lethal temperature of $P$. borchgrevinki was found to be $6{ }^{\circ} \mathrm{C}$ (Somero and DeVries, 1967).

In heart and muscle of common eelpout, concentrations of the anaerobic endproducts lactate and succinate show only a transient rise and are back to control levels after $72 \mathrm{~h}$ at $24^{\circ} \mathrm{C}$. In the liver, however, succinate concentration continued to rise after 1 day of heat exposure. The decrease of anaerobic endproducts during long-term heat exposure is unexpected, but it was observed previously in lugworms, Arenicola marina, from the White Sea (Sommer et al., 1997). This decline could reflect an acclimation of muscle to heat and thus an upward shift of the upper critical temperature. This flexibility of thermal acclimation is likely to be higher in eurythermal than in stenothermal eelpout.

The continuous rise of succinate concentration in the liver implies an irreversible onset of anaerobic metabolism in this organ at the critical temperature in both species. Accumulation of succinate in fish tissues has been observed under both anoxia and functional hypoxia (Johnston and Bernard, 1983; Chew and Ip, 1992). Control levels of succinate, however, are low in fish tissues, especially those poor in mitochondria. The control values in the white muscle of mudskipper at $25^{\circ} \mathrm{C}$ were below the detection limit of $0.05 \mu \mathrm{moll}^{-1} \mathrm{~g}^{-1}$. This is comparable to what we found for both eelpout species $\left(0.02 \mu \mathrm{moll}^{-1} \mathrm{~g}^{-1}\right)$. In addition, the increase to $0.15 \mu \mathrm{moll}^{-1} \mathrm{~g}^{-1}$ in anoxic mudskipper white muscle is only small (Chew and Ip, 1992). Therefore, the contribution of succinate production to ATP formation during anaerobiosis is minor. It is, however, an indicator for oxygen deficiency at the mitochondrial level. In conclusion, the accumulation of anaerobic endproducts at habitat temperatures above a critical threshold not only occurs in invertebrates but also in fish, and may be a universal feature in ectothermic organisms.

In both eelpout species, the energy status of white muscle remained at the control level throughout the experiment, which is reflected in the stable values for $\Delta G / \Delta \xi$ at all temperatures (Tables 2, 3). In Zoarces viviparus, we even observed an increase of $\Delta G / \Delta \xi$ after $24 \mathrm{~h}$ and $72 \mathrm{~h}$ at $24^{\circ} \mathrm{C}$, which was due to a drop in $\mathrm{P}_{\mathrm{i}}$ and a rise in ATP. The Gibbs free energy change of ATP hydrolysis is a measure of the energy content of ATP available to cellular ATPases and is thus the driving force behind ATPases. $\Delta G / \Delta \xi$ remained at values above $-60 \mathrm{~kJ} \mathrm{~mol}^{-}$ 1 at all times, which is well above the critical threshold of -45 to $-52 \mathrm{~kJ} \mathrm{~mol}^{-1}$ (Kammermeier, 1987). Such a drop in $\Delta G / \Delta \xi$ below this critical threshold was found for both eelpout species after strenuous exercise, making it a potential candidate for the cause of muscular fatigue in fish (Hardewig et al., 1998). Recent ${ }^{31} \mathrm{P}-\mathrm{NMR}$ investigations on critical heat exposure in cod, Gadus morhua, showed that in this species heat exposure does not lead to a depletion of energy stores until just before the fish died (F. J. Sartoris, C. Bock and H. O. Pörtner, unpublished data). As a corollary, disturbances in energy status of the white musculature of fish are not indicative of thermal intolerance and are only to be expected in the final phases before heat death. This is in contrast to previous observations in invertebrate musculature where thermal stress caused a drop in $\Delta G / \Delta \xi$ in the mantle muscle of cephalopods (S. Zielinski and H.O. Pörtner, unpublished results) and the body wall muscle of Sipunculus nudus (Zielinski and Pörtner, 1996). However, there is one fundamental difference between the muscle tissue so far studied in invertebrates and fish white muscle. The invertebrate muscles studied are involved in ventilation and thus active even under resting conditions, whereas fish white muscle is not and muscle metabolism may be downregulated during thermal stress. In future research, it would be worthwhile verifying whether the energy status of other, possibly more sensitive, organs of fish such as liver or ventilating muscle are affected in an earlier stage of temperature stress.

\section{Why do fish die at critically high temperatures?}

The important question of why fish die at critically high temperatures remains to be answered. We have shown that both eelpout species accumulate anaerobic end products at their upper critical temperature, at least in the liver tissue. This may be due either to insufficient supply of oxygen to the tissues at critically high temperatures or to temperature-induced dysfunction of the electron transport chain of the mitochondria. Failure of the electron transport chain would lead to an accumulation of $\mathrm{NADH}$, and might elicit formation of anaerobic endproducts. However, a study of heat tolerance in isolated mitochondria of the Antarctic Notothenioids Trematotus bernachii and Lepidonotothen nudifrons showed that mitochondrial respiration is not impaired over a broad temperature range, well beyond the lethal temperature limit, in both species (Weinstein and Somero, 1998; Hardewig et al., 1999). Therefore, the observed accumulation of succinate is probably due to oxygen deficiency rather than to mitochondrial failure. This deficiency is either caused by impaired respiration or insufficient blood circulation, or by a combination of these two factors. In both species, we have observed that oxygen consumption rises steeply at temperatures around the critical temperature. Still, this rise in uptake might be insufficient to cover the rise in oxygen requirements, especially in those organs such as liver, with a high mitochondrial density and consequently a high metabolic rate. So the accumulation of anaerobic endproducts occurs during a situation that is clearly time-limited, and which will finally lead to the death of the animal. The differences in thermal tolerance between the two eelpout species may be correlated with the Arrhenius activation energy of their oxygen consumption rate. A high activation 
energy, as observed in the stenothermal Antarctic eelpout, leads to a steep increase of oxygen consumption with temperature such that oxygen limitation occurs at a lower temperature than in the eurythermal species with a lower Arrhenius activation energy.

Our data suggest that the switch to anaerobiosis is one important element, but other factors may contribute to heat death. Membranes are known to be very sensitive to temperature changes and are even reported as the critical targets in cellular heat death (Bowler and Manning, 1994). A thermal perturbation of membranes would, however, cause severe disturbances in the $\mathrm{pH}$ gradients over cell membranes and an alkalisation of the intracellular milieu. In contrast, an acidosis developed in the white muscle. Therefore, we do not feel that a general breakdown of membrane function is responsible for heat death in eelpout. It is, however, possible that membranes in tissues other than white muscle were more sensitive to the hyperthermic conditions.

With $P$. brachycephalum, we observed that the animals lost balance after $10 \mathrm{~h}$ at $10^{\circ} \mathrm{C}$. Such an observation of imbalance at the upper critical temperature was also made with cod Gadus morhua (F. J. Sartoris, C. Bock and H. O. Pörtner, unpublished results) and goldfish (Friedlander et al., 1976). This loss of balance points towards a failure in the central nervous system. Evidence in favour of a particular sensitivity of the central nervous system to temperature extremes comes from a study by Friedlander and coworkers (1976). In goldfish, they found that progressive localised heating of the brain induced the same sequence of behavioural deficits as those observed during heat stress: (1) irritability, (2) increased swimming movements, (3) motor incoordination and finally, (4) coma, with irregular or stopped breathing. This confirms that respiratory failure, in some cases in combination with circulatory failure, is probably the final cause of heat death in fish or even, as data on invertebrates suggest, ectotherms in general (Pörtner et al., 1998).

The thermal sensitivity of acetylcholinesterase might be responsible for neuronal disturbances at high temperatures and may be involved in the onset of respiratory failure. Acetylcholinesterase is responsible for the quick degradation of the neurotransmitter acetylcholine after its release. First evidence for a particular heat sensitivity of this enzyme in Antarctic fish came from a study by Baldwin on Pagothenia borchgrevinki (1971). Enzyme-substrate affinity dropped between $2{ }^{\circ} \mathrm{C}$ and $10^{\circ} \mathrm{C}$ by a factor of 35 , whereas in tropical fish a three- to fourfold decrease was observed over a broad temperature range. Baldwin and Hochachka (1970) looked at the two isoforms of acetylcholinesterase in trout brain. The authors found that the isoform present in cold-acclimated fish rapidly lost substrate affinity at temperatures above $10^{\circ} \mathrm{C}$. In the temperature range above $10^{\circ} \mathrm{C}$ another isoform became predominant, and only this second isoform was present in $18^{\circ} \mathrm{C}$ acclimated fish. A crucial role of this enzyme in heat-induced mortality in fish, however, still needs to be substantiated.

In summary, our study provides some evidence for oxygen limitation of heat tolerance in Antarctic and temperate eelpout. This is linked to the thermal sensitivity of metabolic rate and to a transition to anaerobic metabolism at temperatures above the upper critical threshold. Future work should address the reasons for a differential heat sensitivity of various organs and the molecular mechanisms involved in setting and shifting the thermal limits of organisms, and also between different populations.

This work is a contribution to the ELOISE project: Effects of climate-induced temperature change on marine coastal fishes (CLICOFI) ENV-CT97-0596, funded by the European Union. ELOISE publication No. 100; AWI publication No. 1603.

\section{References}

Albrecht, M. L. (1982). The influence of keeping conditions on the physiological status and the growth rate of carp in warm water. Fortschr. Fischereiwiss. 1, 55-63.

Andriashev A. P. (1986). Zoarcidae. In Fishes of the North-eastern Atlantic and the Mediterranean, Vol. III (ed. E. A. Whitehead), pp. 1130-1150. Paris: UNESCO.

Baldwin, J. (1971). Adaptation of enzymes to temperature: acetylcholinesterase in the central nervous system of fishes. Comp. Biochem. Physiol. 40, 181-187.

Baldwin, J. and Hochachka, P. W. (1970). Functional significance of isoenzymes in thermal acclimation: acetylcholinesterase from trout brain. Biochem. J. 116, 883-887.

Beamish, F. W. H. (1963). Seasonal changes in the standard rate of oxygen consumption of fishes. Can. J. of Zool. 42,177-188.

Bergmeyer, H. U. (1985). Methods of Enzymatic Analysis, vols 1-12 (3rd edition). Weinheim, Germany.

Bowler, K. and Manning, R. (1994). Membranes as the critical targets in cellular heat injury and resistance adaptation. In Temperature Adaptation of Biological Membranes (ed. A. R. Cossins), pp. 185-203. London: Portland Press.

Chew, S. F. and Ip, Y. K. (1992). Biochemical adaptations of the mudskipper Boleophthalmus boddaerti to a lack of oxygen. Mar. Biol. 112, 567-571.

Childress, J. J. (1995). Are there physiological and biochemical adaptations of metabolism in deep-sea animals? In Biochemistry and Molecular Biology of Fishes, vol. 5 (ed. P. W. Hochachka and T. Mommsen), 175-196. London: Elsevier Science BV.

Clarke, A. (1991). What is cold adaptation and how should we measure it? Am. Zool. 31, 81-92.

Egginton, S., Taylor, E. W., Wilson, R. W., Johnston, I. A. and Moon, T. W. (1991). Stress response in the Antarctic teleosts (Notothenia neglecta Nybelin and N. rossii Richardson). J. Fish Biol. 38, 225-235.

Ekau, W. (1988). Ökomorphologie nototheniider Fische aus dem Weddellmeer, Antarktis. Ber. Polarforsch. 51, 1-140.

Friedlander, M. J., Kotchabhakdi, N. and Prosser, C. L. (1976). Effects of cold and heat on behaviour and cerebellar function in goldfish. J. Comp. Physiol. 112, 19-45.

Grieshaber, M. K., Hardewig, I., Kreutzer, U. and Pörtner, H. O. (1994). Physiological and metabolic responses to hypoxia in invertebrates. Rev. Physiol. Biochem. Pharmacol. 125, 43-147.

Hardewig, I., van Dijk, P. L. M. and Pörtner, H. O. (1998). Highenergy turnover at low temperatures: recovery from exhaustive exercise in Antarctic and temperate eelpouts. Am. J. Physiol. 274, R1789-R1796. 
Hardewig, I., Peck, L. S. and Pörtner, H. O. (1999). Thermal sensitivity of mitochondrial function in the Antarctic Notothenioid Lepidonotothen nudifrons. J. Comp. Physiol B 169, 597-604.

Hochachka, P. W. and Somero, G. N. (1984). Biochemical Adaptation, 537 pp. Princeton: University Press.

Holeton, G. F. (1974). Metabolic cold adaptation of polar fish: fact or artefact? Physiol. Zool. 47, 137-152.

Johnston, I. A. and Bernard, L. M. (1983). Utilization of the ethanol pathway in carp following exposure to anoxia. J. Exp. Biol. 104, 73-78.

Johnston, I. A., Clark, A. and Ward, P. (1991). Temperature and metabolic rate in sedentary fish from the Antarctic, North Sea and Indo-West Pacific Ocean. Mar. Biol. 109, 191-195.

Kammermeier, H. (1987). High energy phosphate of the myocardium: contraction versus free energy change. Basic Res. Cardiol. 82 (Suppl. 2), 31-36.

Kindle, K. R. and Whitmore, D. H. (1986). Biochemical indicators of thermal stress in tilapia aurea. J. Fish Biol. 29, 243-255.

Leach, G. J. and Taylor, M. H. (1980). The role of cortisol in stressinduced metabolic changes in Fundulus heteroclitus. Gen. Comp. Endocrinol. 42, 219-227.

Mazeaud, M. M., Mazeaud, F. and Donaldson, E. M. (1977). Primary and secundary effects of stress in fish: some new data with a general overview. Trans. Mer. Fish. Soc. 106, 201-212.

McDonald, D. G. (1983). Interaction of environmental calcium and low $\mathrm{pH}$ on the physiology of the rainbow trout, Salmo gairdneri. I. Branchial and renal net ion and $\mathrm{H}^{+}$fluxes. J. Exp. Biol. 102, 123-140.

Moerland, T. S. and Egginton, S. (1998). Intracellular pH of muscle and temperature: Insight from in vivo ${ }^{31} \mathrm{P}$ NMR measurements in a stenothermal teleost (Harpagifer antarcticus). J. therm. Biol. 23, 275-282.

Mohnen, V. A. and Wang, W. C. (1992). An overview of global warming. Environm. Tox. Chem. 11, 1051-1059.

Morris, D. J. and North, A. W. (1984). Oxygen consumption of five species of fish from South Georgia. J. Exp. Mar. Biol. Ecol. 78, 75-86.

Noack, S. (1980). Statistische Auswertung von Meß- und Versuchsdaten mit Taschenrechner und Tischcomputer, pp. 373-382. Berlin: Walter de Gruyter.

Pörtner, H. O. Boutilier, R. G., Tang, Y. and Toews, D. P. (1990). Determination of intracellular $\mathrm{pH}$ and $\mathrm{P}_{\mathrm{CO}_{2}}$ after metabolic inhibition by fluoride and nitrilotriacetic acid. Respir. Physiol. 81, 255-274.

Pörtner, H. O., Finke, E. and Lee, P. G. (1996). Effective Gibb's free energy change of ATP hydrolysis and metabolic correlates of intracellular $\mathrm{pH}$ in progressive fatigue of squid (Lolliguncula brevis) mantle muscle. Am. J. Physiol. 271, R1403-R1414.

Pörtner, H. O., Hardewig, I. Sartoris, F. J. and Van Dijk, P. L. M. (1998). Energetic aspects of cold adaptation: critical temperatures in metabolic, ionic and acid-base regulation? In Cold Ocean Physiology (ed. H. O. Pörtner and R. Playle), pp. 88-120. Cambridge: University Press.

Reeves, R. B. (1972). An imidazole alphastat hypothesis for vertebrate acid-base regulation: Tissue carbon dioxide content and body temperature in bullfrogs. Resp. Physiol. 14, 219-236.

Ryan, S. N. (1995). The effect of chronic heat stress on cortisol levels in the Antarctic fish Pagothenia borchgrevinki. Experientia 51, 768-774.
Somero, G. N. and DeVries A. L. (1967). Temperature tolerance of some Antarctic fishes. Science 156, 257-258.

Sommer, A., Klein, B. and Pörtner, H. O. (1997). Temperature induced anaerobiosis in two populations of the polychaete worm Arenicola marina. J. Comp. Physiol. B 167, 25-35.

Southward, A. J., Hawkins, S. J. and Burrows, M. T. (1995). Seventy years' observation of changes in distribution and abundance of zooplankton and intertidal organisms in the western English channel in relation to rising sea temperature. J. Therm. Biol. 20, 127-155.

Staurnes, M., Rainuzzo, J. R., Sigholt, T., and Jorgensen, L. (1994). Acclimation of atlantic cod (Gadus morhua) to cold water: stress response, osmoregulation, gill lipid composition and gill $\mathrm{Na}^{+}-\mathrm{K}^{+}$ ATPase activity. Comp. Biochem. Physiol. 109A, 413-421.

Teague, W. E. and Dobson, G. P. (1992). Effect of temperature on the creatine kinase equilibrium. J. Biol. Chem. 267, 14084-14093.

Tewari, Y. B., Goldberg, R. N. and Advani, J. V. (1991). Thermodynamics of the disproportionation of adenosine $5^{\prime}$ diphosphate to adenosine $5^{\prime}$-triphosphate and adenosine 5 monophosphate. II. Experimental data. Biophys. Chem. 40, 263-276.

Torres, J. J. and Somero, G. N. (1988a). Vertical distribution and metabolism in antarctic mesopelagic fishes. Comp. Biochem. Physiol. 90B, 521-528.

Torres, J. J. and Somero, G. N. (1988b). Metabolism, enzymatic activities, and cold adaptation in antarctic mesopelagic fishes. Mar. Biol. 98, 169-180.

van Dijk, P. L. M., van den Thilllart, G. E. E. J. M. and Wendelaar Bonga, S. E. (1993). Is there a synergistic effect between steady state exercise and water acidification in carp? J. Fish Biol. 42, 673-681.

van Dijk, P. L. M., Hardewig, I. and Pörtner, H. O. (1997). Temperature-dependent shift of $\mathrm{pH}_{\mathrm{i}}$ in fish white muscle: contributions of passive and active processes. Am. J. Physiol. 272, R84-R89.

van Dijk, P. L. M., Hardewig, I. and Pörtner, H. O. (1998). Exercise in the cold: high energy turnover in Antarctic fish. In Fishes of Antarctica. A Biological Overview (ed. G. di Prisco, E. Pisano and A. Clarke), pp. 225-236. Milan: Springer-Verlag.

von Dorrien, C. F. (1993). Ökologie und respiration ausgewählter arktischer Bodenfischarten. Ber. Polarforsch. 125, 1-99.

Weinstein, R. B. and Somero, G. N. (1998). Effects of temperature on mitochondrial function in the Antarctic fish Trematomus bernacchii. J. Comp Physiol. B 168, 190-196.

Wells, R. M. (1987). Respiration of Antarctic fish from McMurdo Sound. Comp. Biochem. Physiol. 88A, 417-424.

Wohlschlag, D. E. (1963). An Antarctic fish with unuasually low metabolism. Ecology 44, 557-564.

Wohlschlag, D. E. (1964). Respiratory metabolism and growth of some antarctic fishes. In Biologie Antarctique (ed. R. Garrick, M. W. Holdgate and J. Prevost), pp. 489-502. Paris: SCAR Symposium, Hermann.

Zielinski, S. and Pörtner, H. O. (1996). Energy metabolism and ATP free-energy change of the intertidal worm, Sipunculus nudus, below a critical temperature. J. comp. Physiol. B 166, 492-500.

Zimmermann, C. and Hubold, G. (1998). Respiration and activity of Arctic and Antarctic fish with different modes of life: A multivariate analysis of experimental data. In Fishes of Antarctica. A Biological Overview (ed. G. di Prisco, E. Pisano and A. Clarke), pp. 163-174. Milan: Springer-Verlag. 